\title{
Antioxidant Activity of Natural Products against Aluminium Fluoride Induced Oxidative Stress
}

\author{
Ganapaty $\mathbf{S}^{1}$, Chandrashekhar $\mathrm{VM}^{2^{*}}$, Lakshmi Narasu $\mathrm{M}^{3}$, Raghavendra $\mathrm{HL}^{4}$ \\ ${ }^{1}$ Pharmacognosy and Phytochemistry Division, College of Pharmaceutical Sciences, \\ Andhra University, Visakhapatnam-530003, Andhra Pradesh, India \\ ${ }^{2}$ Department of Pharmacology, Hanagal Shri Kumareshwar College of Pharmacy, B.V.V.S. Campus, \\ Bagalkot-587101, Karnataka, India \\ ${ }^{3}$ Center of Biotechnology, Institute of Science and Technology, JNTU, Hyderabad-500072, \\ Andhra Pradesh, India \\ ${ }^{4}$ Faculty of Medical Sciences, Wollega University, Post Box No: 395, Nekemte, Ethiopia
}

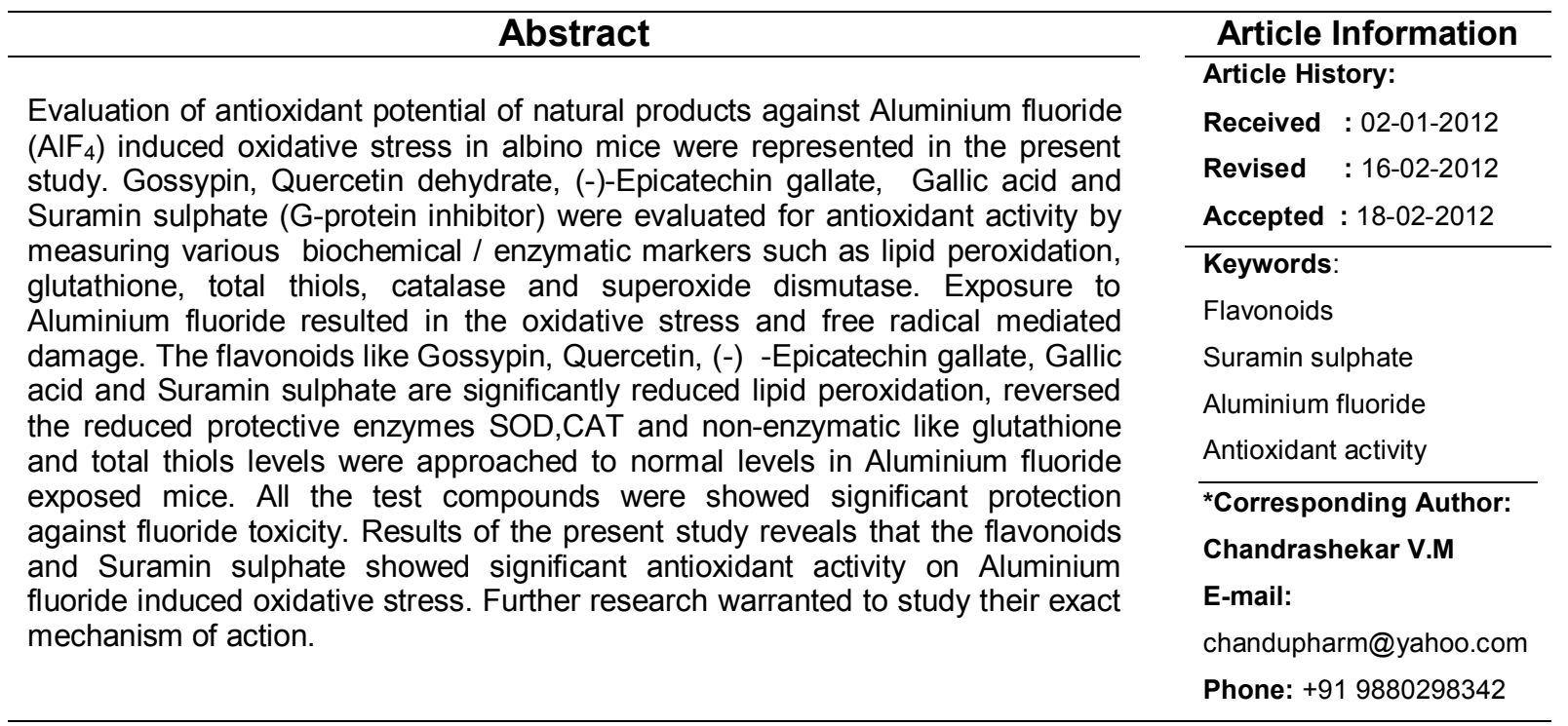

\section{INTRODUCTION}

Over the last several years, numerous reports from China, India and elsewhere indicate that fluoride in varying concentrations induces free radical toxicity in both animals and in people living in areas of endemic fluorosis. There is much evidence that superoxide free radical and lipid peroxidation play an important role in fluorosis (Chinoy, 2003). Laboratory investigations have often used fluoride activation for stimulation of guanine nucleotide binding proteins (G-Proteins) and activation of adenylate cyclase depends on traces of aluminium (Gilman, 1987; Sternweis \& Gilman, 1982). These metallofluoride complexes may thus mimic or potentates the action of numerous extracellular signals and significantly affects many cellular responses.

Fluoride in the presence of trace amounts of Aluminium affects blood elements, cells of the 
immune system, protein phosphorylation and organization of cytoskeleton proteins, processes of calcium homeostasis, ion transport and energy metabolism (Ann strunecka \& Tiri patocka, 1999). Also include abnormal behavior patters, altered neuronal and cerebrovascular integrity (Mullenix et al., 1995). In blood, brain and liver tissues of animals, various changes occur after chronic administration of fluoride are generation of free radicals, lipid peroxidation and altered antioxidant defense systems are considered to play an important role in the toxic effects of fluoride (Rzeuski et al., 1998; Sharm \& Chinoy, 1998).

Defense mechanism against free radical induced oxidative stress involved preventative mechanisms, mainly by enzymatic antioxidant defenses include superoxide dismatase (SOD), glutathione peroxidase (GPx), catalase (CAT), non-enzymatic antioxidants are ascorbic acid (Vitamin C), alph-tocopherol (Vitamin E), glutathione (GSH), plant derived polyphenolic and flavonoids are showed antioxidant properties. This balance is essential for the survival of organism and their health.

The protection offered by dietary flavonoids and phenolic compounds have generally been considered as non-nutrients and their possible beneficial effect on human health has only recently been recognized. These compounds are known to possess anti-inflammatory, neuroprotective, radioprotection and anticarcinogenic activities (Rajnaryana et al., 2001; Ganapaty, 2007). On this above basis, in our study we evaluated antioxidant properties of different flavonoids and Suramin sulphate against Aluminium fluoride (G-protein activator) induced oxidative stress in mice.

\section{MATERIALS AND METHODS}

\section{Materials Required}

Quercetin dehydrate, (-)-Epicatechin gallatee, Suramin sulphate, Nitro blue tetrazolium (NBT), Thiobarbituric acid (TBA), 1,2-dithio-bisnitrobenzoic acid (DTNB) and Aluminium fluoride were obtained from the Sigma chemical Co (St. Louis, MO,USA) and Trichloroacetic acid (TCA), Hydroxylamine HCL were obtained from Merk, KGOA, Germany. All other chemicals and reagents used were of analytical grade.
Refrigerated centrifuge (Model MPW-350R) from MPW Med. Instrument, Warszawa, Poland and UV-Spectrophotometer (UV-1601) Shimadzu Corporation, Kyoto, Japan were used. The flavonoid gossypin was isolated from Hibiscus vitifolius in Prof. S. Ganapaty's laboratory and was used in this study.

\section{Animal Care}

Swiss albino mice weighing in between 20-24 $\mathrm{g}$ were used for the study. They were kept for one week in our laboratories before the experiments for acclimatization to the laboratory conditions and fed with low-fluoride food and water Ad libitum. Animal care and protocols were in accordance with and approved by the Institutional Animal Ethics Committee, Hanagal Shri Kumareshwara college of Pharmacy, B.V.V.S. Campus, Bagalkot-587101, Karnataka, India (IAEC/05/01-09). All mice were housed in polypropylene cages in a temperature $\left(25 \pm 2{ }^{\circ} \mathrm{C}\right)$ and humidity $(60 \pm 10 \%)$ controlled room submitted to a 12-dark/light cycle (artificial lights, 7 a.m -7 p.m.) and air exhaustion cycle $(15 \mathrm{~min} / \mathrm{h})$. All procedures were carried out in accordance with the conventional guidelines for experimentation with animals. Prior to experimental treatments, animals were fasted overnight but were allowed free access to water. Six animals were used for each group of study.

\section{Experimental Procedure}

The activity was carried out with slightly modification of method described by Sinha et al. (2007). Mice were divided into seven groups of six animals each. Group I, receives normal saline serves as control and group II, receives Aluminium fluoride treated group. Group III, IV, $\mathrm{V}, \mathrm{VI}$ and $\mathrm{VII}$ treated with Gossypin $(10 \mathrm{mg} / \mathrm{Kg}$ body wt) i.p, Quercetin dehydrate $(10 \mathrm{mg} / \mathrm{Kg}$ body wt) i.p,(-)-Epicatechin gallate $(10 \mathrm{mg} / \mathrm{Kg}$ body wt) i.p ,Gallic acid (10 mg / Kg body wt) i.p and Suramin sulphate (5 $\mathrm{mg} / \mathrm{Kg}$ body $w$ t) i.p respectively for the period of 14 days and from $7^{\text {th }}$ day onwards Aluminium fluoride (600 ppm) treatment through their drinking water. After 24 hrs the last dose of Aluminium fluoride administration, all the animals were sacrificed by cervical decapitation, brain and liver was removed and washed in cold $0.9 \%$ saline, kept on ice and subsequently blotted on filter paper, then weighed and homogenized in cold phosphate buffer $(0.1 \mathrm{M}, \mathrm{pH} 7.4)$ using a potter Elvehjem Teflon homogenizer as possible as under standard condition and homogenate was kept on ice until assayed. 


\section{Biochemical Estimations Total Protein}

The protein contents of $10 \%$ liver homogenates were determined by using the modified Lowry's method (Lowry et al., 1951).

\section{Lipid Peroxidation (LPO)}

A Thiobarbituric acid reactive substance (TBARS) in the homogenate was estimated by using standard protocol (Prabhakar et al., 2006). Briefly, the $0.5 \mathrm{ml}$ of $10 \%$ homogenate was incubated with $15 \%$ TCA, $0.375 \%$ TBA and $5 \mathrm{~N} \mathrm{HCl}$ at $95{ }^{\circ} \mathrm{C}$ for $15 \mathrm{~min}$, the mixture was cooled, centrifuged and absorbance of the supernatant measured at $512 \mathrm{~nm}$ against appropriate blank. The amount of lipid peroxidation was determined by using $\varepsilon=1.56$ $\times 10^{5} \mathrm{M}^{-1} \mathrm{~cm}^{-1}$ and expressed as TBARS nmoles/ mg of protein (Braughler et al., 1987).

\section{Superoxide Dismutase (SOD)}

Superoxide dismutase activity was determined based on the ability of SOD to inhibit the auto-oxidation of epinephrine to adrenochrome at alkaline $\mathrm{pH}$ (Misra and Fridovich, 1972). Briefly, $25 \mu \mathrm{l}$ of the supernatant obtained from the centrifuged liver homogenate was added to a mixture of $0.1 \mathrm{mM}$ adrenaline in carbonate buffer (10.2) in a total volume of $1 \mathrm{ml}$ and the formation of adrenochrome was measured at $295 \mathrm{~nm}$. The SOD activity (U/mg of protein) was calculated by using the standard plot.

\section{Catalase (CAT)}

Catalase activity was assayed by the method of Claiborne (1985). Breiefly, the assay mixture consisted of $1.95 \mathrm{ml}$ phosphate buffer $(0.05 \mathrm{M}$, $\mathrm{pH} 7.0), 1.0 \mathrm{ml}$ hydrogen peroxide $(0.019 \mathrm{M})$ , and $0.05 \mathrm{ml}$ homogenate $(10 \%, \mathrm{w} / \mathrm{v})$ in a total volume of $3.0 \mathrm{ml}$. changes in absorbance were recorded at $240 \mathrm{~nm}$. Catalase activity was calculated in terms of units /mg protein.

\section{Total Thiols}

This assay is based on the principle of formation of relatively stable yellow color by sulphydryl groups with DTNB (Moron et al., 1979). Briefly, $0.2 \mathrm{ml}$ of liver homogenate was mixed with phosphate buffer $(\mathrm{pH} \mathrm{8.0),} 40 \mu \mathrm{l}$ of $10 \mathrm{mM}$ DTNB and $3.16 \mathrm{ml}$ of methanol. This mixture was incubated for $10 \mathrm{~min}$ and the absorbance was measured at $412 \mathrm{~nm}$ against appropriate blanks. The Total thiol content was calculated by using $\varepsilon=13.6 \times 10^{3} \mathrm{~cm}^{-1} \mathrm{M}^{-1}$ (Sedlak \& Lindsy, 1978).

\section{Glutathione (GSH)}

Briefly, proteins were precipitated using $10 \%$ TCA, centrifuged and $0.5 \mathrm{ml}$ of the supernatant was mixed with $0.2 \mathrm{M}$ phosphate buffer ( $\mathrm{pH} 8.0$ ) and $0.006 \mathrm{mM}$ DTNB. This mixture was incubated for $10 \mathrm{~min}$ and the absorbance was measured at $412 \mathrm{~nm}$ against appropriate blanks. The glutathione content was calculated by using the standard plot under same experimental conditions (Prabhakar et al., 2007).

\section{Histopathology}

The mice were sacrificed under light ether anesthesia, liver samples of all group were preserved in $10 \%$ neutral buffered formalin as described by Luna (1968). Liver 5-6 $\mu \mathrm{m}$ thickness were cut and stained with hematoxylin and eosin.

\section{Statistical Analysis}

All the data were expressed as mean \pm SEM. The significance of difference in means between control and treated animals for different parameters was determined by using one-way ANOVA followed by Dennett's' test. Significance of differences between groups was evaluated with Students $t$-test. A $p$-value of $<0.05$ was considered statistically significant.

\section{RESULTS}

\section{Lipid Peroxidation}

Normal mice showed basal TBARS levels of about $35.25 \pm 1.521$ and $31.91 \pm 3.023 \mathrm{nmol} / \mathrm{mg}$ of protein of brain and liver homogenate respectively. Different flavonoids (drug control) did not show a significant difference in lipid peroxidation activity as compared to control. Mice treated with Aluminium fluoride showed significant $(p<0.001)$ increases in the TBARS levels to about $133.7 \pm 9.703$ and $79.31 \pm 7.810$ $\mathrm{nmoles} / \mathrm{mg}$ of protein of brain and liver tissues homogenate in comparison to the normal control. Different flavonoids like Gossypin (10 $\mathrm{mg} / \mathrm{Kg}$ ), Quercetin dehydrate $(10 \mathrm{mg} / \mathrm{Kg})$, (-)Epicatechin gallate $(10 \mathrm{mg} / \mathrm{kg})$, Gallic acid (10 $\mathrm{mg} / \mathrm{Kg})$ and Suramin sulphate $(5 \mathrm{mg} / \mathrm{Kg})$ a $\mathrm{G}$ protein inhibitor in $\mathrm{AlF}_{4}$ exposed mice showed reduced levels of TBARS significantly to about $55.38 \pm 4.302,54.05 \pm 8.099,40.56 \pm 4.619,74.01$ \pm 12.51 and $69.86 \pm 5.503 \mathrm{nmoles} / \mathrm{mg}$ of protein of brain tissue and 40.59 $\pm 1.53(p<0.001), 57.92$ $\pm 5.302(p<0.05), 45.41 \pm 6.326(p<0.01), 37.83$ $\pm 2.006(p<0.001)$ and $67.89 \pm 7.587 \mathrm{nmoles} / \mathrm{mg}$ of protein in comparison to Aluminium fluoride treated groups (Figure $1 \& 2$ ). 


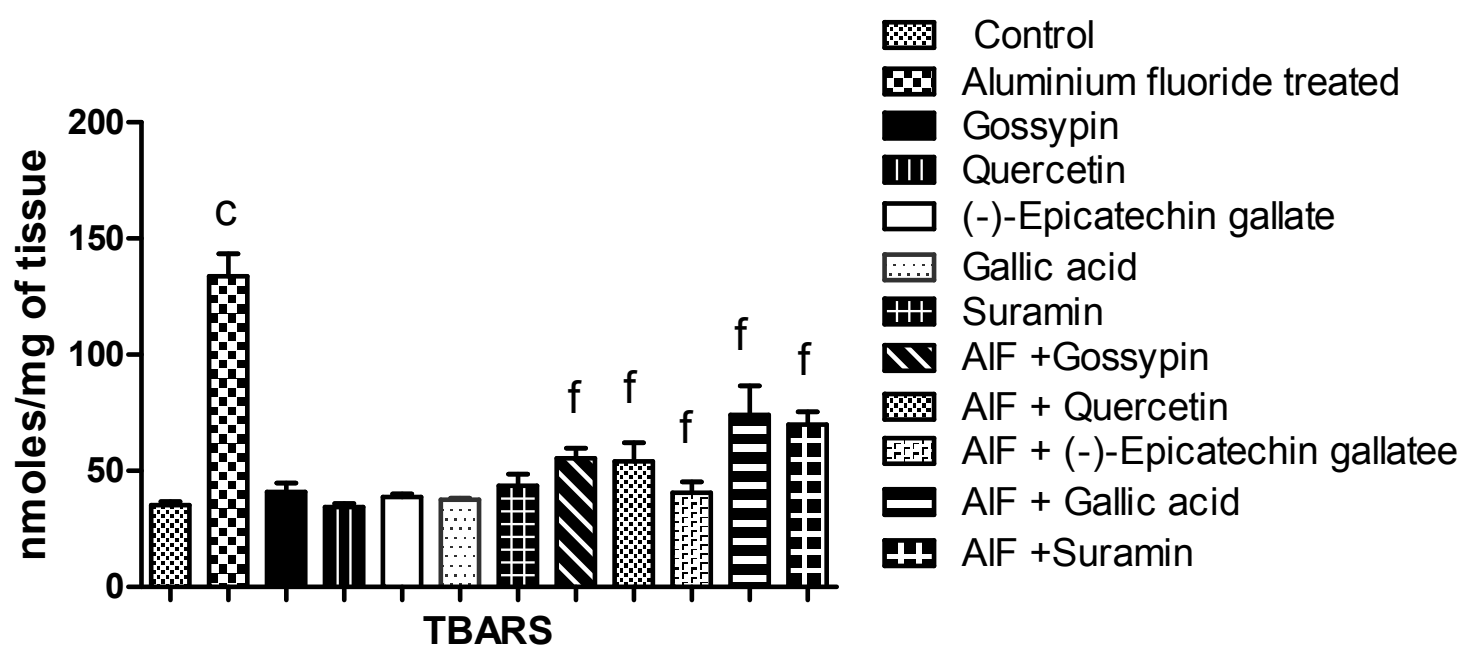

Figure 1. Estimation of TBARS in the brain homogenates of mice which received Aluminium fluoride in drinking water and drug treatment. Statistical significance: ${ }^{\mathrm{a}} p<0.05 ;{ }^{\mathrm{b}} p<0.01 ;{ }^{\mathrm{c}} p<0.001 \mathrm{Vs}$ Normal control; ${ }^{\mathrm{d}} p<0.05 ;{ }^{\mathrm{e}} p<0.01 ; ;^{\mathrm{f}} p<0.001$ Vs Aluminium fluoride treated group.

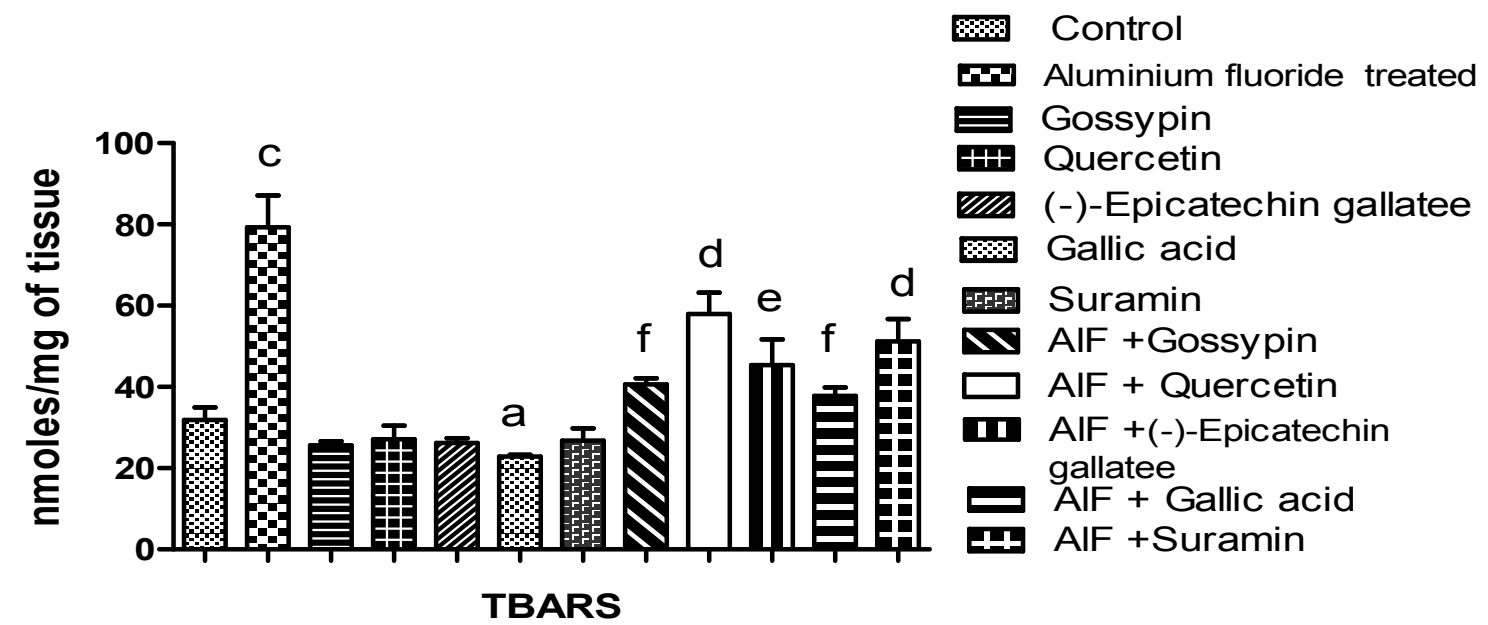

Figure 2. Estimation of TBARS in the liver in homogenates of mice which received Aluminium fluoride in drinking water and drug treatment. Statistical significance: ${ }^{\mathrm{a}} p<0.05 ;{ }^{\mathrm{b}} p<0.01 ;{ }^{\mathrm{c}} p<0.001 \mathrm{Vs}$ Normal control; ${ }^{\mathrm{d}} p<0.05 ;^{\mathrm{e}} p<0.01 ;^{\mathrm{f}} p<0.001$ Vs Aluminium fluoride treated group.

\section{Total Thiols}

Normal basal total thiol was found to be 14.29 \pm 0.726 and $15.82 \pm 1.683 \mu \mathrm{mol} / \mathrm{mg}$ of protein of brain and liver tissue of homogenate. Different flavonoids solutions (drug control) did not show a significant difference activity comparison to control. Mice treated with Aluminium fluoride treated decreased the levels $6.014 \pm 0.9705$ and $4.516 \pm 0.335 \mu \mathrm{mol} / \mathrm{mg}$ of protein of brain and liver tissue homogenate respectively as compression to control. The total thiols were should significant $(p<0.001)$ increased and reversed to normal level. $\mathrm{AlF}_{4}$ exposed mice with different flavonoids like, Gossypin (10 $\mathrm{mg} / \mathrm{Kg})$, Quercetin dehydrate $(10 \mathrm{mg} / \mathrm{Kg})$, (-)Epicatechin gallate $(10 \mathrm{mg} / \mathrm{kg})$, Gallic acid $(10$ $\mathrm{mg} / \mathrm{Kg}$ ) and Suramin sulphate $(5 \mathrm{mg} / \mathrm{Kg})$ of about in brain homogenate 14.71 $\pm 0.956,17.41$ $\pm 1.884, \quad 12.93 \pm 1.124, \quad 10.25 \pm 0.879 \quad(p<0.01)$, $16.72 \pm 1.237 \mu \mathrm{mol} / \mathrm{mg}$ of protein respectively and liver homogenate of about $21.19 \pm 2.992$, $19.22 \pm 2.252, \quad 20.52 \pm 1.820, \quad 9.250 \pm 0.771$ and $17.50 \pm 2.084 \mu \mathrm{mol} / \mathrm{mg}$ of protein respectively as comparison with the Aluminum fluoride treated group (Figure $3 \& 4$ ). 


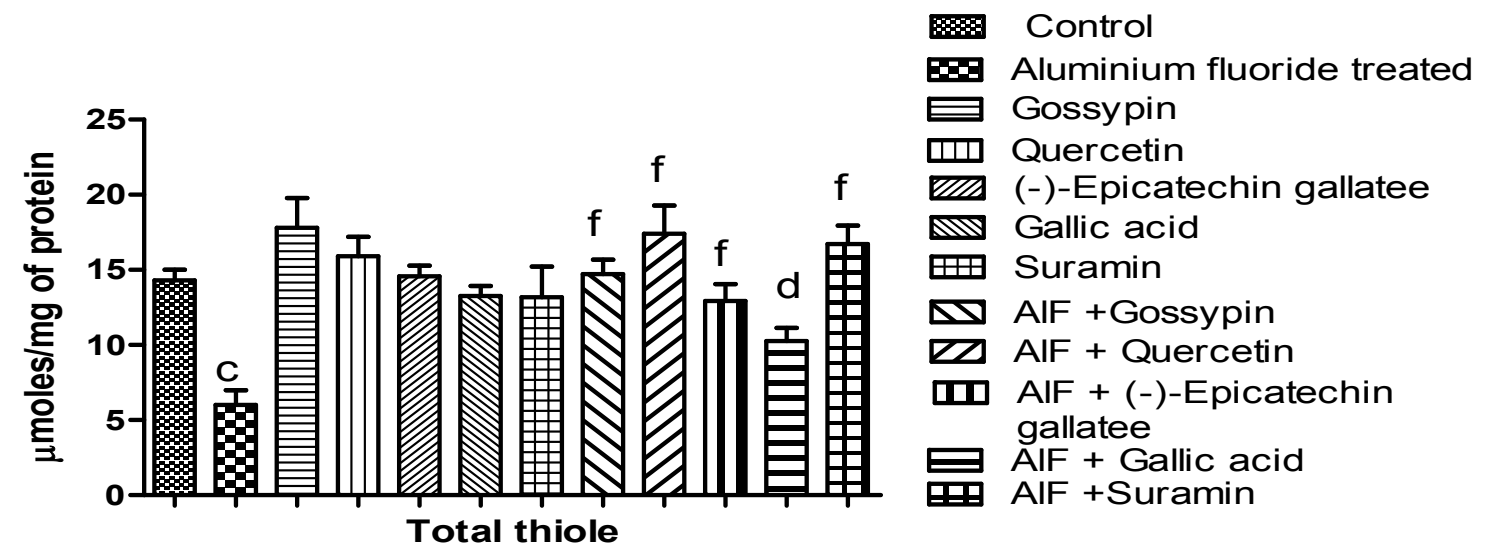

Figure 3. Estimation of total thiols in the brain homogenates of mice which received Aluminium fluoride in drinking water and drug treatment. Statistical significance: ${ }^{\mathrm{a}} p<0.05 ;{ }^{\mathrm{b}} p<0.01 ;{ }^{\mathrm{c}} p<0.001$ Vs Normal control; ${ }^{\mathrm{d}} p<0.05 ;{ }^{\mathrm{e}} p<0.01 ;{ }^{\mathrm{f}} p<0.001$ Vs Aluminium fluoride treated group.

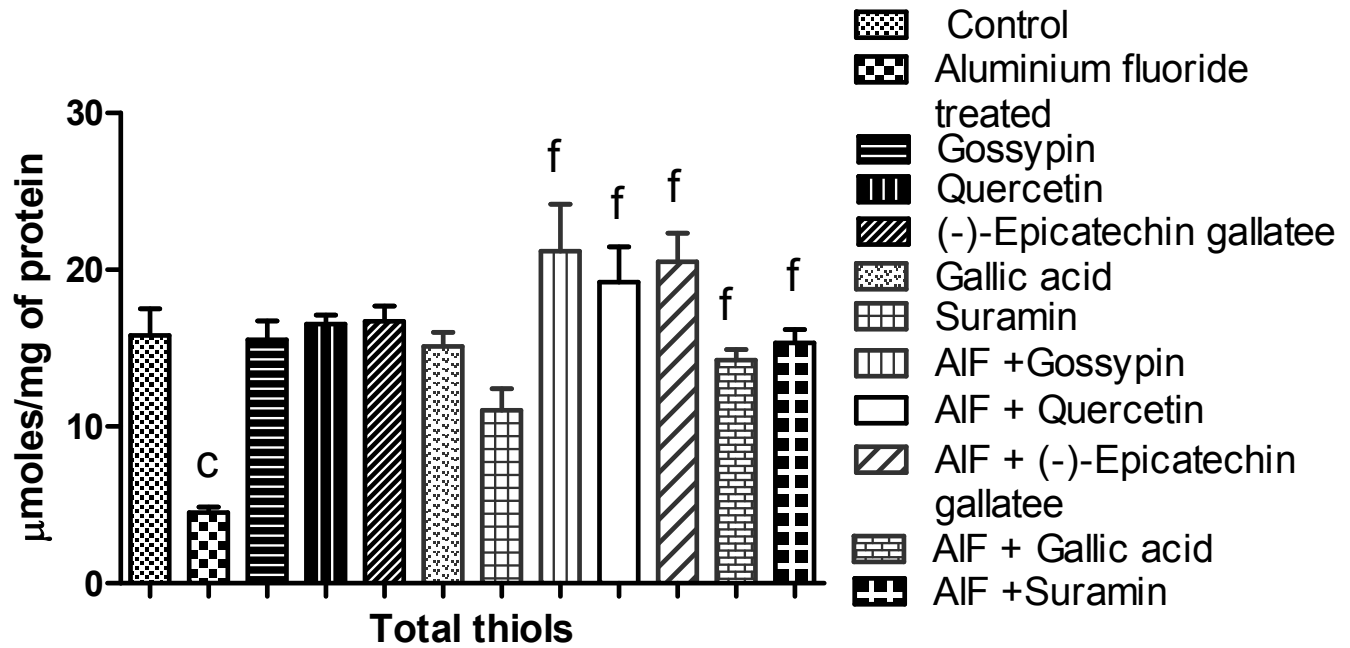

Figure 4. Estimation of total thiols in the liver homogenates of mice which received Aluminium fluoride in drinking water and drug treatment. Statistical significance: ${ }^{\mathrm{a}} p<0.05 ;{ }^{b} p<0.01 ;{ }^{\mathrm{c}} p<0.001 \mathrm{Vs}$ Normal control; ${ }^{\mathrm{d}} p<0.05 ;{ }^{\mathrm{e}} p<0.01 ; ;^{\mathrm{f}} p<0.001$ Vs Aluminium fluoride treated group.

\section{Superoxide Dismutase}

Normal basal level of SOD activity was found to be $17.60 \pm 2.811$ and $16.24 \pm 1.073 \mathrm{U} / \mathrm{mg}$ of protein of brain and liver homogenate. Different flavonoids (drug control) did not show a significant difference in SOD activity compared control. Mice treated with Aluminium fluoride decreased the levels of about $5.114 \pm 0.291$ and $3.213 \pm 0.423$ in and liver tissue homogenate respectively as comparison to normal control. Different flavonoids in Aluminium fluoride treated groups reversed significantly $(p<0.001)$ the SOD level to normal.
Gossypin (10 mg/Kg), Quercetin dehydrate (10 $\mathrm{mg} / \mathrm{Kg}$ ), (-)-Epicatechin gallate $(10 \mathrm{mg} / \mathrm{kg})$, Gallic acid $(10 \mathrm{mg} / \mathrm{Kg})$ and Suramin sulphate $(5 \mathrm{mg} / \mathrm{Kg})$ a G-protein inhibitor increases the SOD level significantly of about $14.09 \pm 1.303$, $14.25 \pm 1.715,12.27 \pm 0.883,12.77 \pm 0.795$, and $13.09 \pm 1.409$ of brain tissue homogenate and $12.76 \pm 1.763,13.09 \pm 2.394,11.10 \pm 0.638,10.60$ \pm 0.781 and $13.12 \pm 1.409$ of liver tissue homogenate respectively as comparison with the Aluminium fluoride treated group(Figure $5 \&$ $6)$. 


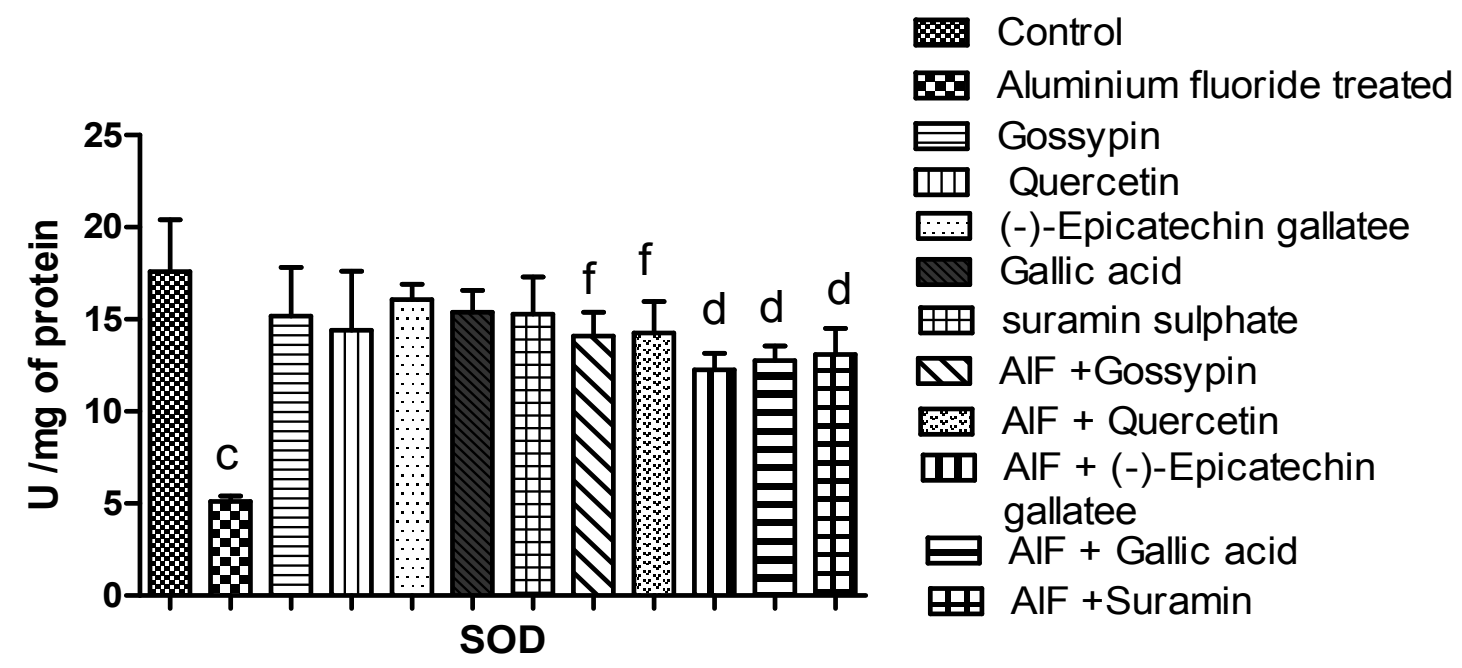

Figure 5. Estimation of superoxide dismutase in the brain homogenates of mice which received Aluminium fluoride in drinking water and drug treatment. Statistical significance: ${ }^{a} p<0.05$; ${ }^{\mathrm{b}} p<0.01 ;{ }^{\mathrm{C}} p<0.001 \mathrm{Vs}$ Normal control; ${ }^{\mathrm{d}} p<0.05 ;{ }^{\mathrm{e}} p<0.01 ;{ }^{\mathrm{f}} p<0.001 \mathrm{Vs}$ Aluminium fluoride treated group.

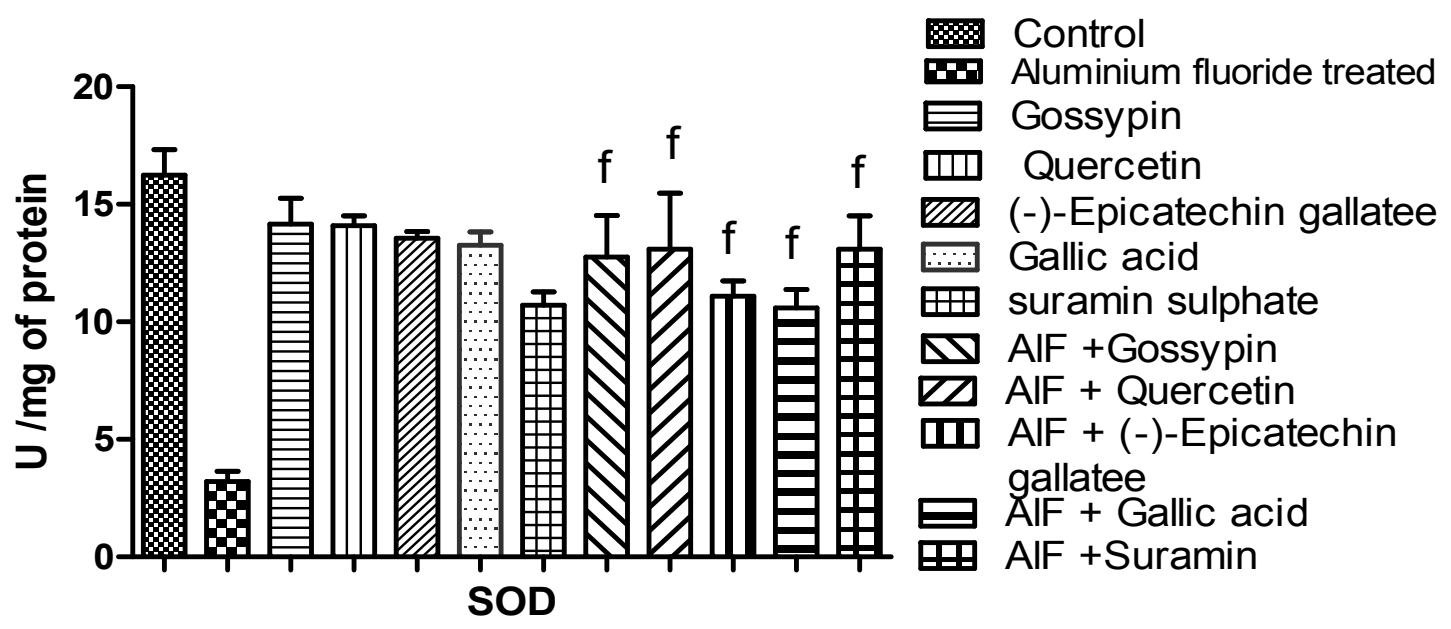

Figure 6. Estimation of superoxide dismutase in the liver homogenates of mice which received Aluminium fluoride in drinking water and drug treatment. Statistical significance: ${ }^{a} p<0.05{ }^{b}$ $p<0.01 ;{ }^{\mathrm{c}} p<0.001 \mathrm{Vs}$ Normal control; ${ }^{d} p<0.05 ;{ }^{\mathrm{e}} p<0.01 ;{ }^{\mathrm{f}} p<0.001$ Vs Aluminium fluoride treated group.

\section{Catalase}

Normal basal level of catalase activity was found to be $2.263 \pm 0.250,0.987 \pm 0.054 \mathrm{U} / \mathrm{mg}$ of protein of brain and liver homogenate. Different flavonoids (drug control) did not show a significant difference in catalase activity compared control. Mice treated with Aluminiumm fluoride decreased the levels of about $0.3597 \pm 0.114$ and $0.9871 \pm 0.054$ of brain and liver tissue homogenate respectively as comparison to normal control. Different flavonoids in Aluminium fluoride treated groups reversed the catalase level to normal. Gossypin

(10mg/Kg), Quercetin dehydrate (10 mg/Kg), (-) -Epicatechin gallate $(10 \mathrm{mg} / \mathrm{kg})$, Gallic acid (10 $\mathrm{mg} / \mathrm{Kg}$ ) and Suramin sulphate $(5 \mathrm{mg} / \mathrm{Kg})$ a Gprotein inhibitor increases the catalase level significantly of about $1.566 \pm 0.134 \quad(p<0.001)$, $1.712 \pm 0.272(p<0.01), 1.169 \pm 0.186 \quad(p<0.01)$, $1.458 \pm 0.2200(p<0.01) \& 0.948 \pm 0.157(p<0.05)$ of brain tissue homogenate respectively and $1.384 \pm 0.294(p<0.01), 1.868 \pm 0.0463(p<0.001)$ and $1.250 \pm 0.248 \quad(p<0.001)$ of liver tissue homogenate respectively as comparison with the Aluminium fluoride treated group (Figure 7 \& 8). 


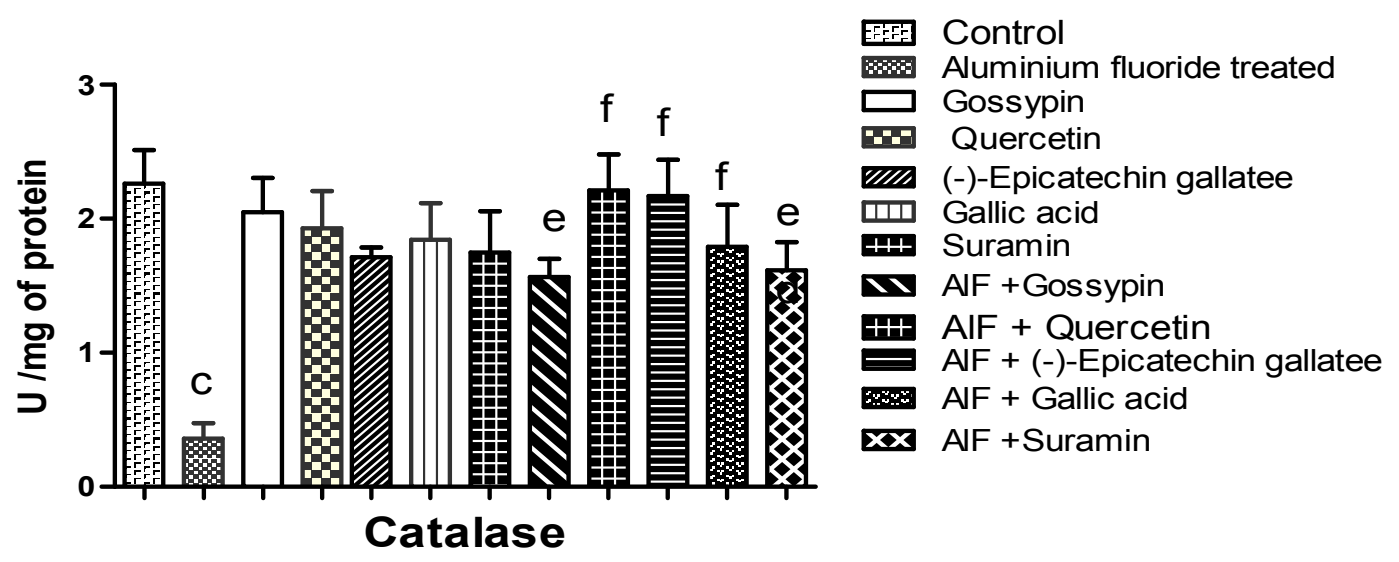

Figure 7. Estimation of catalase in the brain homogenates of mice which received Aluminium fluoride in drinking water and drug treatment. Statistical significance: ${ }^{\mathrm{a}} p<0.05 ;{ }^{\mathrm{b}} p<0.01 ;{ }^{\mathrm{c}} p<0.001 \mathrm{Vs}$ Normal control; ${ }^{\mathrm{d}} p<0.05 ;^{\mathrm{e}} p<0.01 ;{ }^{\mathrm{f}} p<0.001 \mathrm{Vs}$ Aluminium fluoride treated group.

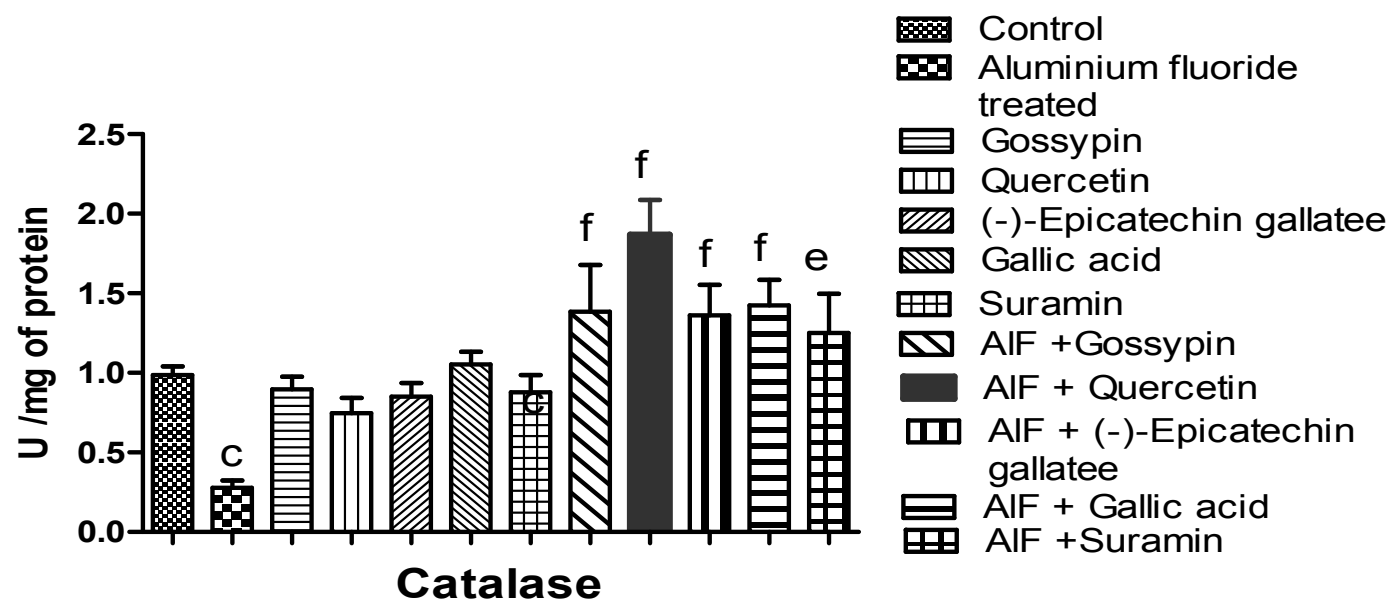

Figure 8. Estimation of catalase in the liver homogenates of mice which received Aluminium fluoride in drinking water and drug treatment. Statistical significance: ${ }^{\mathrm{a}} p<0.05 ;{ }^{\mathrm{b}} p<0.01 ;{ }^{\mathrm{c}} p<0.001 \mathrm{Vs}$ Normal control; ${ }^{\mathrm{d}} p<0.05 ;{ }^{\mathrm{e}} p<0.01{ }^{\mathrm{f}} p<0.001$ Vs Aluminium fluoride treated group.

\section{Glutathione}

Normal basal GSH level was found to be $6.051 \pm 0.428$ and $5.208 \pm 0.335 \mathrm{nmoles} / \mathrm{mg}$ of protein of brain and liver homogenate. Different flavonoids solutions (drug control) did not shown a significant difference activity comparison to normal. Mice treated with Aluminium fluoride treated decreases the levels $2.099 \pm 0.2152$ and $1.691 \pm 0.1187 \mathrm{nmoles} / \mathrm{mg}$ of protein of brain and liver tissue homogenate respectively as compared to normal control. The GSH levels were significantly $(p<0.001)$ increased to normal levels. $\mathrm{AlF}_{4}$ exposed micewith different flavonoids like Gossypin (10 $\mathrm{mg} / \mathrm{Kg})$, Quercetin dehydrate $(10 \mathrm{mg} / \mathrm{Kg}),(-)-$ Epicatechin gallate $(10 \mathrm{mg} / \mathrm{kg})$, Gallic acid $(10$ $\mathrm{mg} / \mathrm{Kg})$ and Suramin sulphate $(5 \mathrm{mg} / \mathrm{Kg})$ increases SOD levels of about 7.262 \pm 0.375 , $7.689 \pm 0.9507,5.290 \pm 0.3608,6.188 \pm 0.4281 \&$ $5.727 \pm 0.489$ of brain tissue homogenate respectively and $5.783 \pm 0.8512,6.779 \pm 0.808$, $7.255 \pm 0.539,6.397 \pm 0.403$ and $5.541 \pm 0.447$ of liver tissue homogenate respectively as comparison with the Aluminium fluoride treated group(Figure $9 \& 10$ ). 


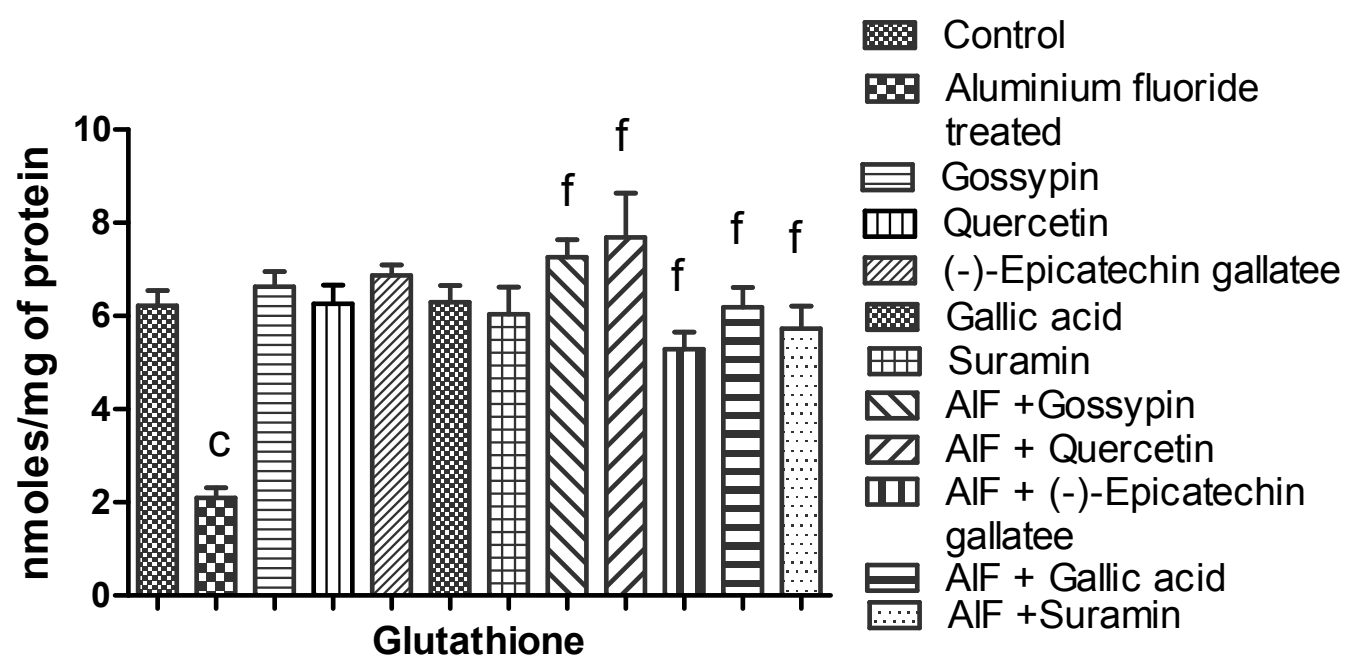

Figure 9. Estimation of glutathione in the brain homogenates of mice which received Aluminium fluoride in drinking water and drug treatment. Statistical significance: ${ }^{\mathrm{a}} p<0.05 ;{ }^{\mathrm{b}} p<0.01 ;{ }^{\mathrm{c}} p<0.001$ Vs Normal control; ${ }^{\mathrm{d}} p<0.05 ;^{\mathrm{e}} p<0.01 ;{ }^{\mathrm{f}} p<0.001$ Vs Aluminium treated group.

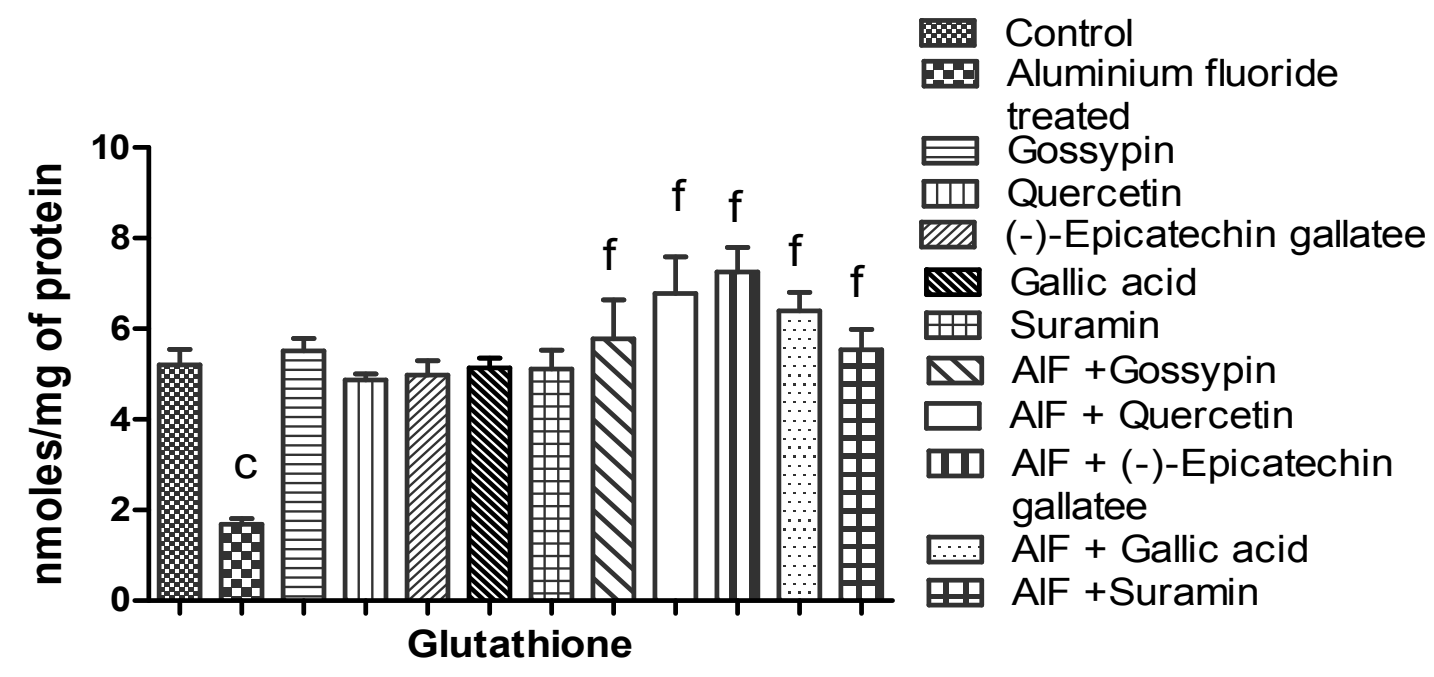

Figure 10. Estimation of glutathione in the liver homogenates of mice which received Aluminium fluoride in drinking water and drug treatment. Statistical significance: ${ }^{a} p<0.05 ;{ }^{b} p<0.01 ;{ }^{c} p<0.001$ Vs Normal control; ${ }^{\mathrm{d}} p<0.05 ;^{\mathrm{e}} p<0.01 ;{ }^{\mathrm{f}} p<0.001$ Vs Aluminium treated group.

\section{Histopatological Examinations}

Histopatological examinations of all the groups were represented from the figure 11-18.

\section{DISCUSSION}

It is conventional wisdom that the oxidative stress response is triggered by an imbalance in
The production and metabolism of reactive oxygen species (ROS). Common oxidants produced in organisms include, reactive oxygen species (ROS), such as hydrogen peroxide, superoxide $\left(\mathrm{O}^{*}\right)$, hydroxy radical $\left(\mathrm{OH}^{-}\right)$, singlet oxygen and nitrogen species. These reactive oxygen species (ROS) has a role in disease and aging in animals (Singh et al., 2002). 


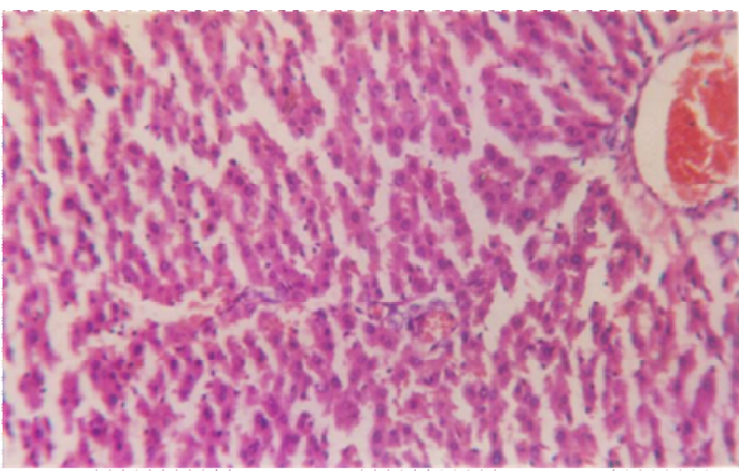

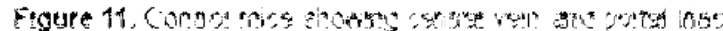

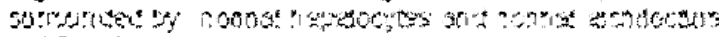
Hes. 20

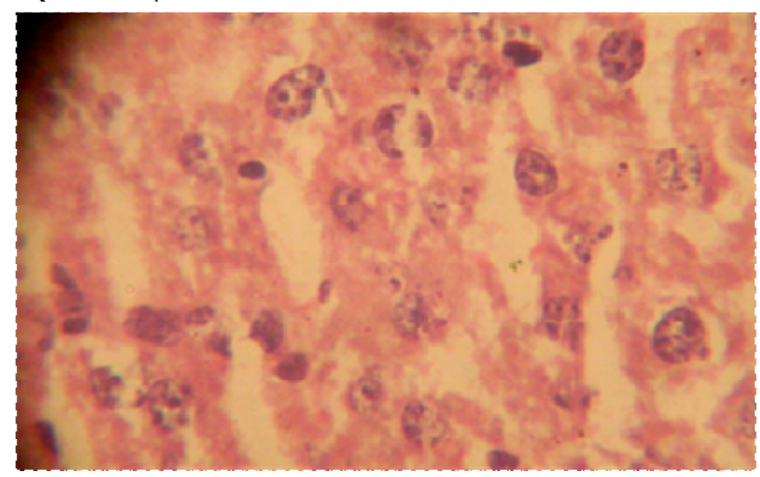

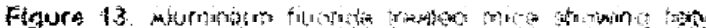

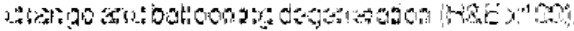

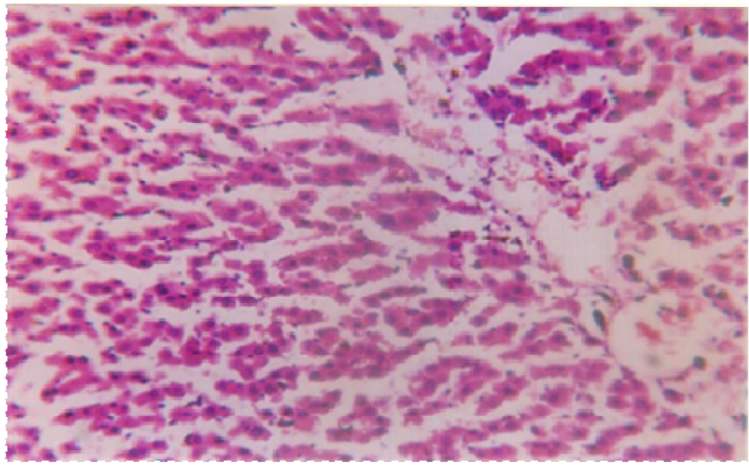

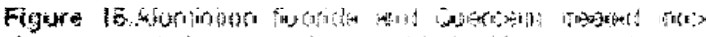

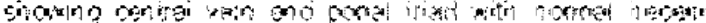

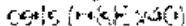

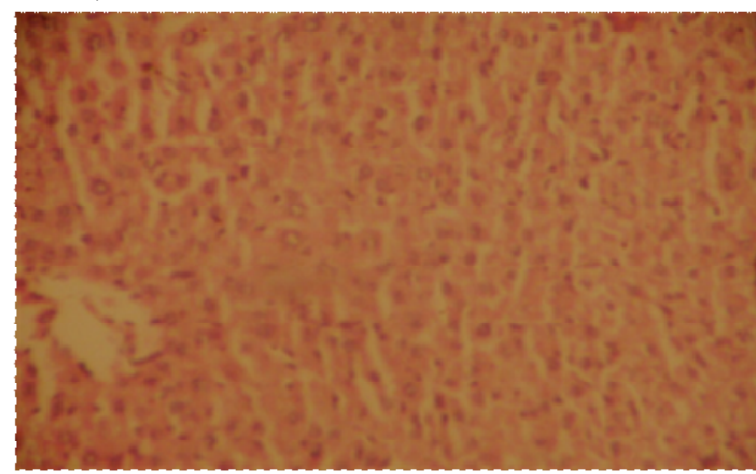

Figure 12, plathith fou

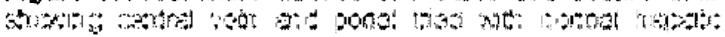
से

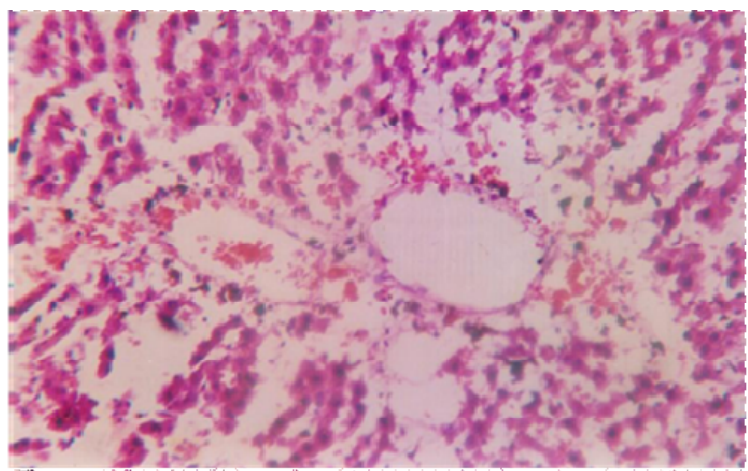

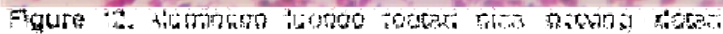

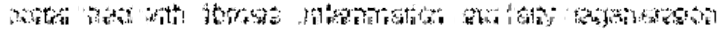
i. $2,+i ;$

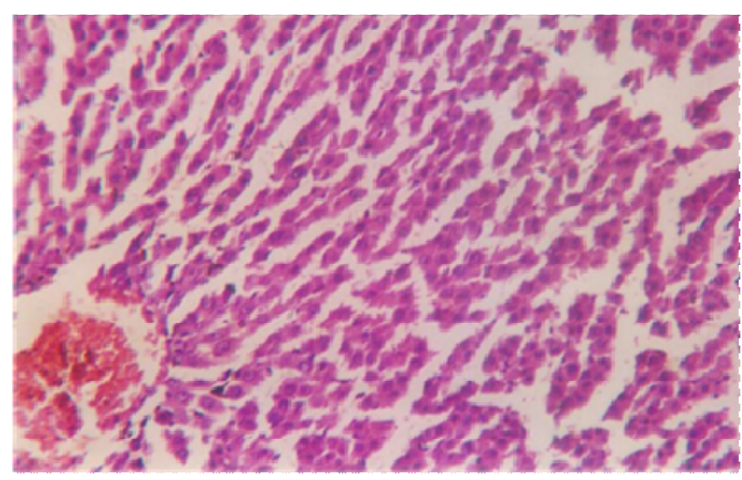

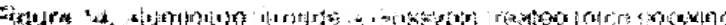

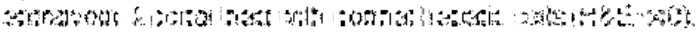

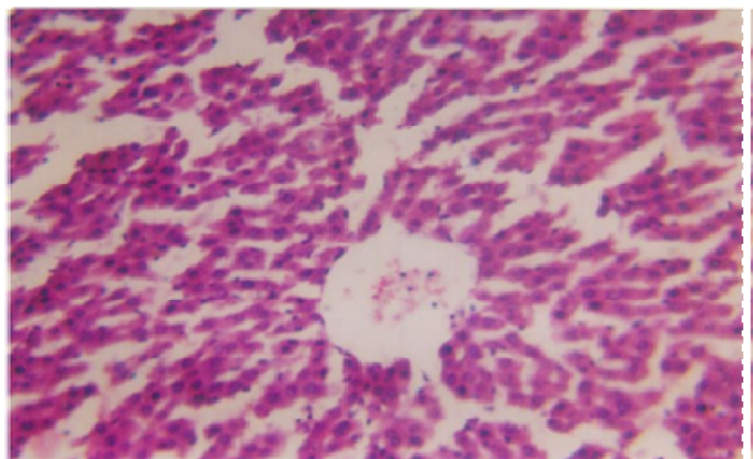

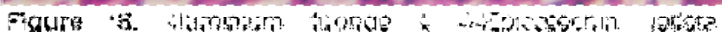

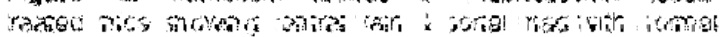

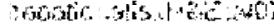

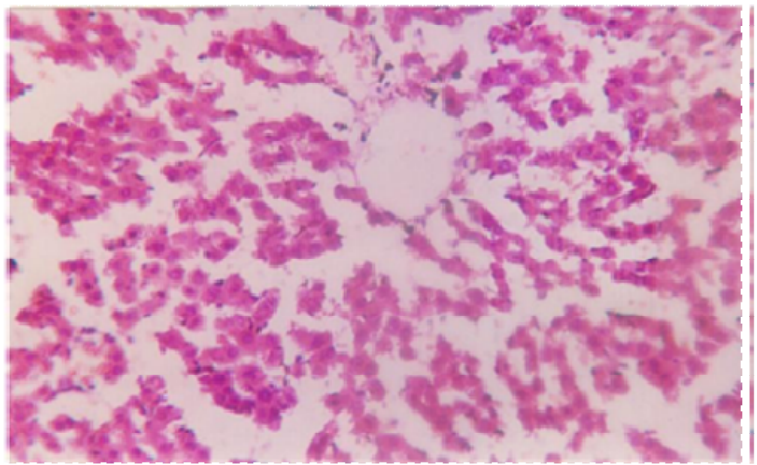

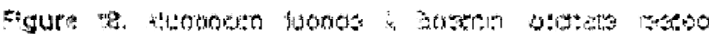

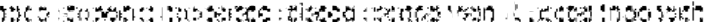
7or 
Ganapaty et al.,

The term redox signaling is used to describe regulatory process in which the signal is delivered through redox reactions. Redox signaling requires that the steady state of redox balance is disturbed either by an increase inROS formation or a decrease in the activity of antioxidant system. Signal transduction is triggered by intracellular signals such as hormones, growth factors, cytokines, neurotransmitters and fluorides (Thannickal \& Fanburg, 2000; Bigay et al., 1987).

Fluoride anions have long been known to influence the activity of a variety of enzymes. Most of the researchers used fluoride activation or stimulation of guanine nucleotide binding protein (G-protein) (Gilman, 1987). Aluminium fluoride complex mimics the action of many neurotransmitters, hormones and growth factors (Sternweis \& Gilman, 1982). The treatment of isolated hepatocytes with sodium fluoride produced an efflux of calcium and rise in free cytosolic calcium, alteration in the phosphatidylionositol-4,5-bisposphate content and increase in the level of inositol -1,4,5triphosphate observed (Chabre, 1999; Blackmore et al., 1985). Similar effects were observed, G-protein mediated cell responses are of key importance in the process of neurotransmission and intracellular signaling in the brain (Blackmore et al., 1988).

Fluoride enhances lipid peroxidation and decreased activities of antioxidant enzymes have been recorded in soft tissue of fluoride treated mice (Rana and Hokin, 1990) and produced changes in organs the reduced in the concentration of free radical scavenger glutathione as well as reduced ascorbic acid and impairments in the activity of the protective enzymes SOD, CAT and reduced GSH (Vani \& Reddy, 2000).

On this basis the present studies with different flavonoids antioxidant properties were evaluated in animals exposed with Aluminium fluoride in drinking water. The results showed the significant antioxidant defense mechanism and protection against oxidative stress. All flvonoids showed significantly decreased the lipid peroxidation, induced by Aluimium fluoride and reveres to the normal level of the protective enzymes catalase, superoxide dismutase, indicating overall fluoride toxicity protective effects.

However, thiols/glutathione content is reported to serve as an index of oxidative stress
Sci. Technol. Arts Res. J., Jan-March 2012; 1(1): 26-37

(Willson, 1983). In our present studies also significant improvement in thiols and glutathione content in both liver and brain. This result indicates that, the selected flavonoids may exert their protection through modulation of signal transduction mechanism via G-protein. Earlier results substantiates that, Suramin sulphate showed significant in G-protein inhibitor (Ref), may be it showed it effects through membrane stabilization and reported to regulates the level of cyclic AMP, which is stimulated by G-protein and inhibiting the intracellular release of calcium, both are critical to the degranulation of mast cells (Sang-Hyun et al., 2005). The flvonoids rich plant extract Lucopus lucidus,showed antioxidant and potent antiallergic activity in compound $48 / 80$ induced mast cell degranulation through inhibits the release of calcium through membrane stabilizing activity through G-proteins and quercetin also showed potent inhibition of histamine released ,which may act by altering intracellular levels of cAMP (Madelein Ennis et al., 1980; Jae-Yong Shin et al., 2005). With the above basis, present selected flavonoids and G-protein inhibitor Suramin suphate (direct inhibitor of Adenylyl cyclase) (Jiri Stohr et al., 2005) may exert their actions as a antioxidant activity and decreased the fluoride toxicity through regulating the cyclic AMP level or modulate adenyl cyclase activity and inhibition of intracellular calcium release, calcium play an important role in increase of intracellular rise of ROS and oxidative stress (Russell, 2004).

In short, $\mathrm{ALF}_{4}$ induced damage produces alteration in the antioxidant status of the tissues, which is manifested as an abnormal histopathology. All flavonoids restored all these changes. The flavonoids have potent antioxidant activity in $\mathrm{AlF}_{4}$ induced oxidative stress.

\section{CONCLUSION}

The results of the present study indicates that, all the tested flavonoids exerts remarkable antioxidant activity due to its possible multiple effects involving significant protection against the oxidative damage, which may be attributed to its protective action on lipid peroxidation and to the enhancing effect on cellular antioxidant defense contributing to the protection against oxidative damage in Aluimium fluoride induced oxidative stress. Further work is necessary to elucidate the molecular mechanism involved in the antioxidant activity of these compounds. 


\section{REFERENCES}

Ann strunecka and Tiri patocka. (1999). Pharmacological and toxicological effects of Aluminium fluoride complexes. Fluoride 32(4): 230-242.

Bigay, J., Deterre, P., Pfister, C., Chabre, M. (1987). Fluoride complexes of aluminium or beryllium act on G-proteins as reversibly bound analogs of the gama- phaosphate of GTP. EMBO Journal 6: 2907-2913.

Blackmore, P.F., Bocckino, S.B., Waynick, L.E., Extron, J.H. (1985). Role of aguanine nucleotide binding regulatory protein in the hydrolysis of hepatocyte phospatidylinositol 4,5-bisposphate by calcium -mobilizing hormones and the control of cell calcium. Studies utilizing aluminum fluoride. Journal of Biological Chemistry 260: 14477-14483.

Blackmore, P.F., Lynch, C.J., Uhing, R.J., Fitzgerald, T., Bocckino, S.B., Exton, J.H. (1988). Role of guanine nucleotide regulatory proteins and inositol phosphates in the hormones induced mobilization of hepatocyte calcium. Advances in Experimental Medicine and Biology 232: 169-182.

Braughler, J.M., Chase, R.L., Pregenzer, J.F. (1987). Oxidation of ferrous iron during peroxidation of various lipid substrates. Biochimica et Biophysica Acta 921: 457-464.

Chabre, M. (1999). Aluminiumfluoride and beryllofluoride complexes, new phosphate analogs in enzymology. TIBS 15: 6-10.

Chinoy, N.J. (2003). Fluoride stress on antioxidant defense systems. Fluoride 36(3): 138-141.

Claiborne, L. (1985). Handbook of methods or oxygen radical research. CRC Press, Londan.

Ganapaty, S., Chandrashekhar, V.M., Chitme, H.R., Lakashmi Narsu, M. (2007). Free radical scavenging activity of gossypin and nevadensin: An in-vitro evaluation. Indian Journal of Pharmacology 39(6): 281-283.

Gilman, A.G. (1987). G-proteins, transducers of receptor-generated signals. Annual Review of Biochemistry 56: 615-49.

Gilman, A.G. (1987). G-proteins, transducers of receptor-generated signals. Annual Review of Biochemistry 56: 615-649.

Jiri Stohr., Jiri Novotny., Lenka Bourova., Petr Svoboda. (2005). Modulation of adenylyl cyclase activity in young and adult rat brain cortex. Identification of suramin as a direct inhibition of adenylyl cyclase. Journal of Cellular and Molecular Medicine 9(4): 940-952.
Lowry, O.H., Rosenhrough, N.J., Farr, A.L., Randall. (1951). Protein measurement with the Folin phenol reagent. Journal of Biological Chemistry 193: 270280.

Luna, L.G. (1968). Manual of histology, staining methods of Armed forces Institute of Pathology. $3^{\text {rd }}$ edition. New York. McGraw Hill.

Madelein Ennis., Gordon Alkinson., Frederick, L. (1980). Pearce, Inhibition of histamine release induced by compound $48 / 80$ and peptide 401 in the presence and absence of calcium. Implications for the mode of action of antiallergic compounds. Agents and Actions 10(3): 222-228.

Misra, H.P., Fridovich, I. (1972). The role of superoxide anion in the autooxidation of epinephrine and a sample assay for superoxide dismutase. Journal of Biological Chemistry 247: 3170-3175.

Moron, A., De Pierre, J.W., Mannervick, B. (1979). Levels of glutathione, glutathione reductase, glutathione-S-transferase activities in rat liver. Biochimica et Biophysica Acta 582: 67-68.

Mullenix, P.J., Denbesten, P.K., Schunior, A., Kernan, W.T. (1995). Neurotoxicity of sodium fluoride in rats. Neurotoxicology and Teratology 17 : 169-177.

Prabhakar, K.R., Veerapur, V.P., Punit Bansal., Vipan, K.P., Machendar Reddy, K., Bhagath Kumar. (2007). Priyadarsini KI, Unnikrishnan MK. Antioxidant and radioprotective effect of the active fraction of Pilea microphylla (L) ethanolic extract. Chemico-Biological Interactions 165: 22-32.

Prabhakar, K.R., Veerapur, V.P., Vipan Kumar., Priyadarsin, K.I., Rao, B.S.S., Unnikrishnan, M.K. (2006). Evaluation and optimization of radio protective activity of Coronopus didymus Linn. in Yirradiated mice. International Journal of Radiation Boilogy 82(8): 1-12.

Rajnaryana, K., Sripal Reddy, M., Chalavadi, M.R., Krishna, D.R. (2001). Bioflavonoid classification, pharmacological, biochemical effects and therapeutic potential. Indian Journal of Pharmacology 33: 2-16.

Rana, R.S., Hokin, L.E. (1990). Role of posphoinositides in transmembrane signaling. Physiological Reviews 70: 115-164.

Russell, L., Blaylock. (2004). Excitotoxicity: A possible central mechanism in fluoride neurotoxicity; Fluoride 37(4): 301-314. 


\section{Ganapaty et al.,}

Rzeuski, R., Chlubek, D., Machony, Z. (1998). Interactions between fluoride and biological free radical reactions. Fluoride 31: 43-45.

Sang-Hyun, K., Chang-Duk, J., Kyongho Suk., Byung-Ju, C., Hyun-Jeung, L., Seunja Park., Seung Ho, L., Hye-Young Shin., Dae-Keum, K. and Tae-Yong, S. (2006). Gallic acid inhibits histamine release and pro-inflammatory cytokine production in mast cells. Toxicological Sciences 19(1): 123-131.

Sedlak, J., Lindsy, R. (1968). Estimation of total, protein bound, and non-protein sulfhydryl groups in tissue with Ellman's reagent. Analytical Biochemistry 25: 192-205.

Sharm, A., Chinoy, N.J. (1998). Role of free radicals in fluoride -induced toxicity in liver and kidney of mice and its reversal. Fluoride 31:S26.

Shin, T.Y., Kim, S.H., Suk, K., Ha, J.H., Kim, I., Lee, M.G., Jun, C.D., Kim, S.Y., Lim, J.P., Eun, J.S., Shin, H.Y., Kim, H.M. (2005). Antiallergic effects of Lycopus lucidus on mast cell mediated allergy model. Toxicology and Applied Pharmacology 209: 255-262.

Singh, R.P., Chidamaramurthy, K.N., Jayaprakasha, G.K. (2002). Studies on the antioxidant activity of pomegranate (Pnica grantum) peel and seed extracts using in vitro models. Journal of Agricultural and Food Chemistry 50: 81-86.
Sci. Technol. Arts Res. J., Jan-March 2012; 1(1): 26-37

Sinha, M., Manna, P. (2007). Aqueous extract of the bark of Terminalia arjuna plays a protective role against sodium fluoride induced hepatic and renal oxidative stress. Journal of Natural Medicines 61: 251-260.

Sternweis, P.C., Gilman, A.G. (1982). Aluminium, a requirement for activation of the regulatory component of adenylate cyclase by fluoride. Proceedings of the National Academy of Sciences 79: 48888-48891.

Sternweis, P.C., Gilman, A.G. (1982). Aluminium, a requirement for activation of the regulatory component of adenylate cyclase by fluoride. Proceedings of the National Academy of Sciences USA 79: 4888-4891.

Thannickal, V.J., Fanburg, B.L. (2000). Reactive oxygen species in cell signaling. American Journal of Physiology - Lung Cellular and Molecular Physiology 279: L1005-L1028.

Vani, M.L., Reddy, K.P. (2000). Effects of fluoride accumulation on some enzymes of brain and gastrocnemius muscle of mice. Fluoride 33: 17-26.

Willson. (1983). Free radical repair mechanism and the interaction of glutathione, Vit $\mathrm{C}$ and Vit $\mathrm{E}$. In: Nygaard, O.F., Simic, M.G., (Eds.). radioprotectors and anticarcinogens. New york: Academic Press. Pp. 1-22. 